\title{
Streptococcus pneumoniae serotype 19A in Latin America and the Caribbean: a systematic review and meta-analysis, 1990-2010
}

\author{
Elizabeth Castañeda ${ }^{1 *}$, Clara Inés Agudelo ${ }^{1}$, Rodrigo De Antonio², Diego Rosselli ${ }^{3}$, Claudia Calderón ${ }^{4}$, \\ Eduardo Ortega-Barria ${ }^{5}$ and Rómulo E Colindres ${ }^{6}$
}

\begin{abstract}
Background: Pneumococcal conjugate vaccines (PCVs) are in the process of implementation in Latin America. Experience in developed countries has shown that they reduce the incidence of invasive and non-invasive disease. However, there is evidence that the introduction of PCVs in universal mass vaccination programs, combined with inappropriate and extensive use of antibiotics, could be associated to changes in non-PCV serotypes, including serotype 19A. We conducted a systematic review to determine the distribution of serotype 19A, burden of pneumococcal disease and antibiotic resistance in the region.

Methods: We performed a systematic review of serotype 19A data from observational and randomized clinical studies in the region, conducted between 1990 and 2010, for children under 6 years. Pooled prevalence estimates from surveillance activities with confidence intervals were calculated.

Results: We included 100 studies in 22 countries and extracted data from 63. These data reported 19733 serotyped invasive pneumococcal isolates, 3.8\% of which were serotype 19A. Serotype 19A isolates were responsible for $2.4 \%$ acute otitis media episodes, and accounted for $4.1 \%$ and $4.4 \%$ of 4,380 nasopharyngeal isolates from healthy children and in hospital-based/sick children, respectively. This serotype was stable over the twenty years of surveillance in the region. A total of 53.7\% Spn19A isolates from meningitis cases and only $14 \%$ from non meningitis were resistant to penicillin.

Conclusions: Before widespread PCV implementation in this region, serotype 19A was responsible for a relatively small number of pneumococcal disease cases. With increased use of PCVs and a greater number of serotypes included, monitoring S. pneumoniae serotype distribution will be essential for understanding the epidemiology of pneumococcal disease.
\end{abstract}

Keywords: Streptococcus pneumoniae serotype 19A, Latin American and the Caribbean, Resistance to penicillin, Conjugate vaccines, Serotype replacement

\section{Background}

Streptococcus pneumoniae causes invasive pneumococcal disease (IPD), which is often life-threatening in children less than 2 years old, adults older than 65 years old and immunocompromised individuals [1]. Pneumococcus is also the most common cause of bacterial acute otitis media (AOM) and sinusitis in children [1-3].

\footnotetext{
* Correspondence: ecastaneda21@gmail.com

'Instituto Nacional de Salud Bogotá, Bogotá, Colombia

Full list of author information is available at the end of the article
}

The most important virulence factor in pneumococcus is the polysaccharide capsule, which forms the basis for serotyping and vaccine formulation; 93 distinct serotypes have been identified (with the recent inclusion of serotypes $6 \mathrm{C}, 6 \mathrm{D}$ and $11 \mathrm{E}$ ) [3-6]. Worldwide, 20 serotypes account for more than $80 \%$ of IPD, although their prevalence varies by region [4]. A small number of pneumococcal resistant clones, serotypes 14, 23F, 6B, 6A, 9V, $15 \mathrm{~A}, 19 \mathrm{~F}$ and 19A, have spread and display particularly high rates of penicillin non susceptibility (PNSP) as well as multiresistance profiles (MDR) [7].

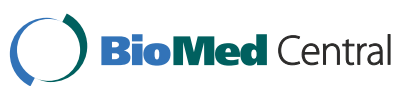


Since the introduction of pneumococcal conjugate vaccines (PCVs), numerous studies have been published on their safety, immunogenicity and efficacy, in particular for the heptavalent vaccine (PCV7), introduced in the USA in $2000[8,9]$. Studies conducted after PCV7 introduction, have shown dramatic and sustained decreases in vaccine type (VT) IPD rates, carriage and herd effects [10-13]. These positive findings were followed by reports of IPD caused by non vaccine types (NVT) S. pneumoniae PNSP and MDR [14-18]. NVT have also been described as agents of non invasive disease [15] and nasopharyngeal carriage [12]. Data from both North America and Europe have shown S. pneumoniae serotype 19A (Spn19A) to be the most prevalent serotype, associated with increasing rates of MDR [19]. Consequently, attention has focused on Spn19A, its prevalence and the numerous factors leading to this increase, and how best to control its impact [20-22].

This review summarizes the available published and unpublished Latin American and Caribbean (LAC) data from 1990 through 2010 describing the prevalence and burden of Spn19A in children less than 6 years. For comparison, we also analyzed the data for the most prevalent serotypes in this region [23].

\section{Methods}

We searched for data collected between January 1990 and July 2010 following PRISMA guidelines. Using both refined search strategies and broad spectrum, low specificity, searches (i.e. "Streptococcus pneumoniae" OR "pneumococcus" anywhere in the text), we reviewed all references on $S$. pneumoniae that were geographically linked to LAC countries, with no language restrictions; the targeted age group was children 6 years-old or younger. We searched the following databases: Medline (PubMed), Embase, Latin American and Caribbean Health Sciences Information (LILACS), Scientific Electronic Library on Line (SciELo) and SCOPUS. Search terms used are shown in Additional file 1a. Abstracts of recent meetings on infectious diseases were also included.

Serotype distribution data were extracted by five reviewers for IPD, non-IPD and nasopharyngeal carriage. In addition, data on Spn19A penicillin susceptibility, pneumococcal disease prevalence and/or incidence, mortality rate, and pneumococcal vaccine potential impact were collected when available. For calculation of impact using SIREVA data we assumed serotype 6A/6B protection for PCV7 and PCV10 [4].

In order to avoid duplicate data, numbers were only added from the databases of the SIREVA Project (only for invasive isolates) available via the PAHO website, [23]. Data included in the analysis: 2000-2005, 2006, 2007, 2008 and 2009, SIREVA corresponded to available information in the original sources published according to the methodology used for this systematic review.
We limited selection bias by reducing the heterogeneity of samples; most data were from the SIREVA network for invasive isolates with standardized laboratory surveillance techniques and expanded availability of protocols. For the inclusion and exclusion criteria used to select publications reporting non IPD studies, we reviewed international criteria and internationally defined and accepted sample collection and laboratory techniques. For the purposes of this systematic review, we adopted the definitions presented in Additional file $1 \mathrm{~b}$.

We analyzed and presented our results following standard guidelines. Prevalence estimates were computed using the number of Spn19A isolates as the numerator and the total number of $S$. pneumoniae reported as denominator, for each study. Two techniques were used to calculate the pooled prevalence estimates: Mantel-Haenszel (fixed-effects model) and DerSimonian-Laird (random-effects model) [24,25].

For invasive disease meta-analysis we only included publications reporting non- SIREVA data, considering that SIREVA data represent $96.7 \%$ of samples analyzed and would bias the pool estimation.

Lastly, we estimated Spn19A specific IPD incidence by multiplying the serotype distribution by the reported incidences identified in this review.

\section{Results}

\section{Study selection}

Our searches retrieved a total of 1704 references. After reviewing the titles and abstracts, a total of 322 full texts were reviewed, 222 of which were excluded. The final number of publications included was 100 and data were extracted from 63; the remaining 37 were referenced (Figure 1). The characteristics of the 63 studies reviewed and of those that were referenced are described in Additional file 2.

The 63 references were divided into three categories: studies with information on invasive serotypes $(n=14)$, non-invasive isolates with individual information $(n=27)$ and burden of disease or disease incidence studies $(n=26)$. Four references provided information on more than one of these categories.

\section{Spn19A in IPD}

Most of the IPD isolates identified came from the SIREVA project (19084 of 19733; 96.7\%) [23,26]. Of these 19733 isolates, $753(3.8 \%)$ were Spn19A. There was no statistically significant difference in the prevalence of Spn19A isolates between SIREVA (3.8\%) and non-SIREVA (3.1\%) data $(\mathrm{p}=0.3)$ (Tables 1 and 2).

When considering countries with more than 500 isolates collected over a period of 17 years (1993-2009) or 10 years (2000-2009) the total number of invasive isolates was $17831 ; 677$ (3.9\%) of these were Spn19A, ranging from $1.5 \%$ in Colombia to $7.0 \%$ in Venezuela (Table 1). 


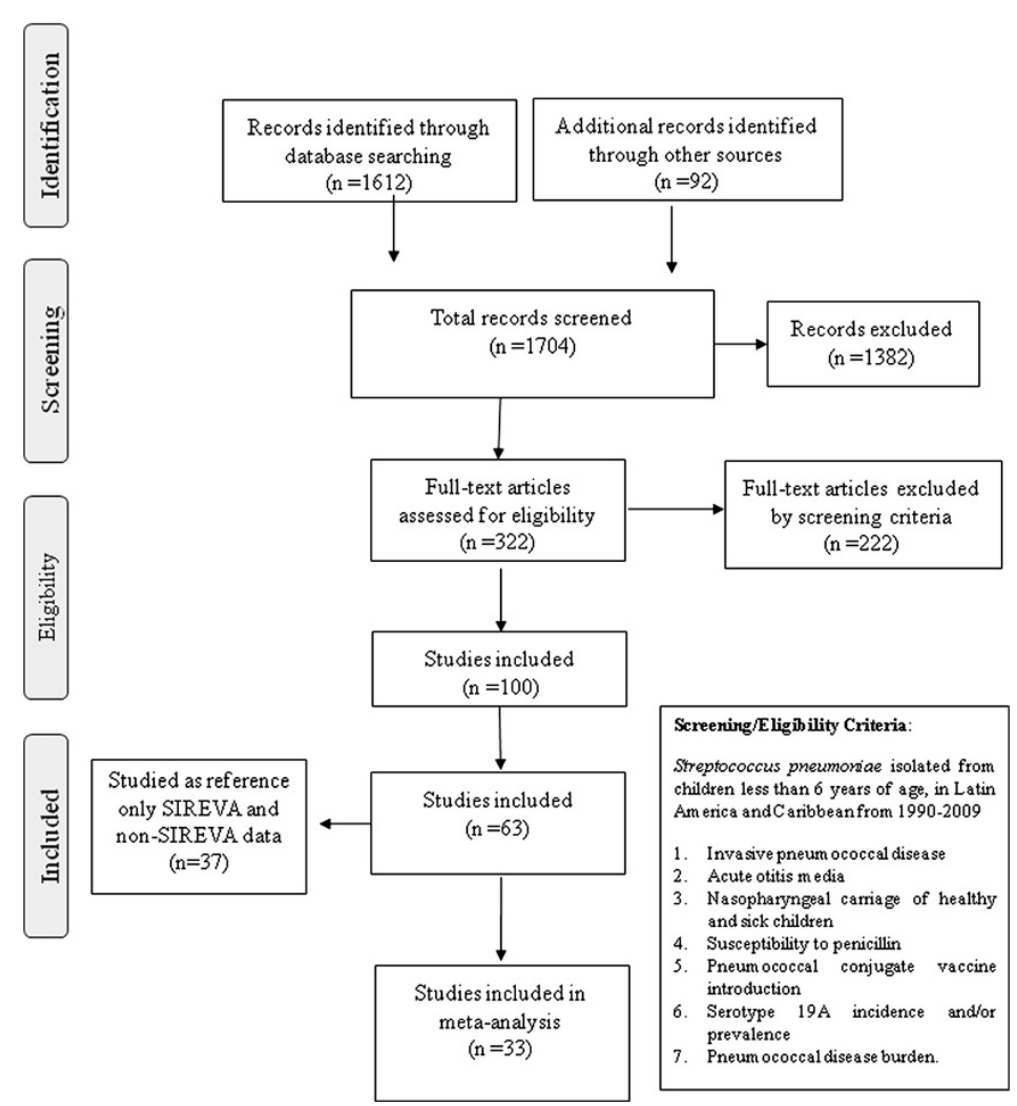

Figure 1 Flow diagram of the literature reviewed.

Analysis of the prevalence of invasive serotypes data from SIREVA (1993-2009) and non SIREVA data (1989-2008) revealed that Spn19A ranked $9^{\text {th }}$ in both sets of data (3.8\% SIREVA and 3.1\% non-SIREVA (See Additional file 3a)). In an analysis of the SIREVA data in 20 countries, Spn19A ranked $9^{\text {th }}(3.6 \%)$ for the period 2000-2005, and $8^{\text {th }}(4.6 \%)$ for the period 2006-2009 (See Additional files $3 \mathrm{~b}$ and $\mathrm{c}$ ).

The prevalence of Spn19A in the region, by country and by time period is shown in Table 3. Spn19A accounted for 3.3\% (CI95\%: 1.8-4.9) of isolates between 1993 and 1999, 3.6\% (CI95\%: 2.3-4.9) between 2000 and 2005 and 4.6\% (C195\%: 3.4-5.8) between 2006 and 2009 ( $\chi 2$ 10.8, p $<0.001)$. The prevalence of serotypes recorded from SIREVA data collected during the three time periods presented by vaccine type (VT) (PCV7, PCV10, PCV13) and non vaccine type (NVT), as well as Spn19A, prevalence by region (SIREVA) (Average cases by study period (20002005 vs. 2006 - 2009) is shown in Additional file 4. Analysis by SIREVA reports are presented in Figure 2.

We did not observe any statistical significant differences in the prevalence of Spn19A isolates reported between age groups $(4.9 \%$ for $<2$ years vs.
$5 \%$ for $2-5$ years; $\mathrm{p}=0.8$ ), for the period $2007-2009$ (See Additional file 5).

Spn19A was reported less frequently in meningitis cases (3.0\%) than in non-meningitis $(4.6 \%$; $p<0.01)$, with the exception of Paraguay (2.8\%vs.2.0\%). Differences were statistically significant only for Brazil (3.0\% vs. $4.8 \%$; $\mathrm{p}=0.009)$ (See Additional file 6a).

SIREVA data from the period 2006-2007 [23] showed that pneumonia accounted for $59.4 \%$ of non-meningitis cases (1069/1801) and 56\% of all Spn19A (42/75). Overall, Spn19A accounted for $3.9 \%$ of the pneumonia isolates in LAC (See Additional file 6b). Data from 2000-2009, showed that Spn19A was the $10^{\text {th }}$ and $6^{\text {th }}$ most frequently reported serotype causing meningitis and non meningitis, respectively (See Additional files $6 \mathrm{c}$ and d).

In non SIREVA data from studies in Argentina [27] and Brazil [29], Spn19A accounted for 1.3\% (2/152) of meningitis and none of the 146 non-meningitis.

\section{Spn19A in AOM}

Data showing the frequency of serotype 19A amongst isolates in cases of acute otitis media are presented in Table 4. Despite representing more than $70 \%$ of the whole sample, 
Table 1 Streptococcus pneumoniae serotype 19A, number of invasive isolates by country, SIREVA data, 1993-2009

\begin{tabular}{|c|c|c|c|c|}
\hline \multirow[t]{2}{*}{ Country } & \multirow{2}{*}{$\begin{array}{l}\text { Year of } \\
\text { isolation }\end{array}$} & \multicolumn{2}{|c|}{ Serotype 19A } & \multirow{2}{*}{$\frac{\text { Total }}{n}$} \\
\hline & & $\mathrm{n}$ & $\%$ & \\
\hline Argentina & 1993-2009 & 100 & 3.7 & 2692 \\
\hline Bolivia & 2000-2009 & 5 & 3.1 & 160 \\
\hline Brazil & 1993-2009 & 153 & 3.6 & 4262 \\
\hline CAREC $^{\mathrm{a}}$ & 2000-2009 & 2 & 1.4 & 148 \\
\hline Chile & 1993-2009 & 161 & 4.5 & 3617 \\
\hline Colombia & 1993-2009 & 28 & 1.5 & 1819 \\
\hline Costa Rica & 2000-2009 & 3 & 4.8 & 63 \\
\hline Cuba & 2000-2009 & 31 & 3.4 & 899 \\
\hline$D R^{b}$ & 2000-2009 & 14 & 2.6 & 544 \\
\hline Ecuador & 2000-2009 & 5 & 2.3 & 215 \\
\hline El Salvador & 2000-2009 & 5 & 9.6 & 52 \\
\hline Guatemala & 2000-2009 & 11 & 9.3 & 118 \\
\hline Honduras & 2000-2009 & 0 & 0.0 & 11 \\
\hline Mexico & 1993-2009 & 91 & 6.2 & 1463 \\
\hline Nicaragua & 2000-2009 & 2 & 4.7 & 43 \\
\hline Panama & 2000-2009 & 15 & 7.7 & 194 \\
\hline Paraguay & 2000-2009 & 17 & 2.2 & 784 \\
\hline Peru & 2000-2009 & 8 & 3.2 & 249 \\
\hline Uruguay & 1993-2009 & 44 & 3.6 & 1210 \\
\hline Venezuela & 2000-2009 & 38 & 7.0 & 541 \\
\hline Total & & 733 & 3.8 & 19084 \\
\hline
\end{tabular}

${ }^{a}$ CAREC: Caribbean Epidemiology Centre. ${ }^{\mathrm{b}}$ DR: Dominican Republic References $[23,26]$.

Number of invasive isolates by country. SIREVA data, 1993-2009.

only $0.6 \%$ of Costa Rican isolates were Spn19A. Data grouped by VT (13, 10 and 7 valent vaccines) and NVT are also shown (See Additional file 7a). Overall, Spn19A accounted for $2.4 \%(11 / 460)$ of isolates, ranking the $9^{\text {th }}$ amongst the most frequent serotype for AOM.

Table 2 Streptococcus pneumoniae serotype 19A, number of invasive isolates by country, non SIREVA data, 1989-2008

\begin{tabular}{|c|c|c|c|c|}
\hline \multirow{2}{*}{$\begin{array}{l}\text { Country } \\
\text { [Reference] }\end{array}$} & \multirow{2}{*}{$\begin{array}{l}\text { Year of } \\
\text { isolation }\end{array}$} & \multicolumn{2}{|c|}{ Serotype $19 \mathrm{~A}$} & \multirow{2}{*}{$\frac{\text { Total }}{n}$} \\
\hline & & $n$ & $\%$ & \\
\hline Argentina $[27]^{a, b}$ & 1999-2002 & 0 & 0.0 & $153^{c}$ \\
\hline Brazil [28] & 1989-1993 & 2 & 4.1 & 49 \\
\hline Brazil [29] ${ }^{a}$ & 1995-1999 & 2 & 1.4 & 145 \\
\hline Chile $[30]^{b}$ & 1994-2004 & 3 & 2.3 & 128 \\
\hline Chile [31] ${ }^{b}$ & 1995-1997 & 1 & 3.3 & 30 \\
\hline Mexico [32] ${ }^{b}$ & 1992-1993 & 11 & 9.2 & 120 \\
\hline Colombia [33] ${ }^{b}$ & 2008 & 1 & 4.2 & 20 \\
\hline Total & & 20 & 3.1 & 649 \\
\hline
\end{tabular}

${ }^{\text {a Meningitis. }}$

${ }^{\mathrm{b}}$ Unspecified invasive disease.

$\mathrm{c} a=7, \mathrm{~b}=146$.
Table 3 Streptococcus pneumoniae serotype 19A prevalence in 20 countries, SIREVA data, 1993-2009

\begin{tabular}{|c|c|c|c|c|c|c|c|c|c|}
\hline \multirow[t]{4}{*}{ Country } & \multicolumn{9}{|c|}{ Periods analyzed [Reference] } \\
\hline & \multicolumn{3}{|c|}{ 1993-1999 [26] } & \multicolumn{3}{|c|}{$2000-2005[23,34]$} & \multicolumn{3}{|c|}{ 2006-2009 [23] } \\
\hline & \multicolumn{2}{|c|}{$19 \mathrm{~A}$} & \multirow{2}{*}{ Total } & \multicolumn{2}{|c|}{$19 \mathrm{~A}$} & \multirow{2}{*}{ Total } & \multicolumn{2}{|c|}{$19 \mathrm{~A}$} & \multirow{2}{*}{ Total } \\
\hline & $\mathrm{n}$ & $\%$ & & $\mathrm{n}$ & $\%$ & & $\mathbf{n}$ & $\%$ & \\
\hline rgentina ${ }^{a}$ & 30 & 3.0 & 1006 & 33 & 3.5 & 936 & 37 & 4.9 & 750 \\
\hline Bolivia & - & - & 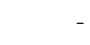 & 3 & 2.8 & 108 & 2 & 3.8 & 52 \\
\hline Brazil & 42 & 3.5 & 1203 & 71 & 3.6 & 1963 & 40 & 3.6 & 1096 \\
\hline CAREC $^{b}$ & - & - & $\begin{array}{lll}- & \\
\end{array}$ & 1 & 0.9 & 110 & 1 & 2.6 & 38 \\
\hline Chile & 19 & 4.1 & 461 & 81 & 4.3 & 1894 & 61 & 4.8 & 1262 \\
\hline Colombia $^{a}$ & 4 & 0.6 & 623 & 6 & 0.9 & 647 & 18 & 3.3 & 549 \\
\hline Costa Rica & - & - & - & 0 & 0.0 & 3 & 3 & 5.0 & 60 \\
\hline Cuba & - & - & - & 28 & 3.3 & 842 & 3 & 5.3 & 57 \\
\hline $\mathrm{DR}^{\mathrm{c}}$ & - & - & - & 8 & 2.1 & 379 & 6 & 3.6 & 165 \\
\hline Ecuador & - & - & - & 0 & 0.0 & 55 & 5 & 3.1 & 160 \\
\hline El Salvador & - & - & - & 3 & 13.0 & 23 & 2 & 6.9 & 29 \\
\hline Guatemala & - & - & - & 4 & 4.4 & 91 & 7 & 25.9 & 27 \\
\hline Honduras & - & - & - & 0 & 0.0 & 3 & 0 & 0.0 & \\
\hline Mexico & 28 & 6.6 & 426 & 42 & 5.8 & 728 & 21 & 6.8 & 309 \\
\hline Nicaragua & - & - & - & 1 & 2.6 & 39 & 1 & 25.0 & \\
\hline Panama & - & - & - & 7 & 6.9 & 101 & 8 & 8.6 & 93 \\
\hline Paraguay & - & - & - & 12 & 2.5 & 477 & 5 & 1.6 & 307 \\
\hline Peru & - & - & - & 3 & 2.1 & 143 & 5 & 4.7 & 106 \\
\hline Uruguay & 13 & 3.7 & 352 & 18 & 3.1 & 575 & 13 & 4.6 & 283 \\
\hline Venezuela & - & - & - & 24 & 5.9 & 407 & 14 & 10.4 & 134 \\
\hline Total & 136 & 3.3 & 4071 & 345 & 3.6 & 9524 & 252 & 4.6 & 5489 \\
\hline
\end{tabular}

${ }^{a}$ Significant differences between 1993-1999 and 2006-2009 (Argentina $p=0.03$, Colombia $p<0.001$.

${ }^{\mathrm{b}}$ Caribbean Epidemiology Centre.

' Dominican Republic.

- No data available.

Prevalence in 20 countries. SIREVA data, 1993-2009.

Spn19A in nasopharyngeal carriage

Spn19A data from isolates in healthy children are shown in Table 4; 20 serotypes were identified for $74.7 \%$ of nasopharyngeal isolates, of which serotype $19 \mathrm{~F}$ was the most frequently reported (13.6 and Spn19A the $6^{\text {th }}$ (4.1\%) (See Additional file 7b).

The distribution of Spn19A in healthy children (carriage) was similar from that seen for the smaller sample of isolates collected from sick children (Table 4), where Spn19A was the $5^{\text {th }}$ most frequently reported serotype (4.4\% of total isolates) (See Additional file 7c).

\section{S. pneumoniae susceptibility to penicillin. Serotype 19A} and other serotypes (2007-2009)

A total of $53.7 \%(22 / 41)$ of Spn19A isolates collected from meningitis cases were reported to be resistant. For non-meningitis isolates $10.8 \%$ of Spn19A isolates (17/ 
158) showed an intermediate level of resistance and 3.2\% (5/158), high resistance (Table 5) [61].

An analysis of other serotypes showed that among 453 resistant meningeal isolates, Spn19A was the $5^{\text {th }}$ most frequently reported serotype (4.9\%) and that, for 248 resistant non-meningitis isolates, it was $3^{\text {rd }}(8.3 \%)$ (See Additional file $8 \mathrm{a}$ ). These data are presented by country in Additional file 8b.

\section{Spn19A meta-analysis}

For invasive disease, our analysis of the data shows $1 \%$ prevalence overall for this serotype, ranging from $0.03 \%$ in Argentina to 9.2\% in Mexico [27-33] (Figure 3a).

The prevalence of Spn19A in AOM was 0.8\%, ranging from $0.6 \%$ in Costa Rica to $16.7 \%$ in Mexico $[35-37,39]$ (Figure $3 \mathrm{~b}$ ).

The overall prevalence of Spn19A in healthy carriers, for 9 different countries, was $2.5 \%$, ranging from $0.4 \%$ for studies conducted in Mexico between 2002 and 2003 period to $10.8 \%$ for studies conducted in Mexico in 2006, respectively [38-56] (Figure 3c). For sick children, the overall prevalence for 4 countries was $2.7 \%$, ranging from $1.6 \%$ in Venezuela to $11.1 \%$ in Brazil [48,54,57-60] (Figure 3d).

\section{Spn19A burden of disease}

Our literature search for publications on the burden of disease caused by serotype 19A identified 26 papers; Table 6 summarizes incidence rates reported. Incidences by country are presented in Additional file 9 .

Lagos et al. [46] monitored IPD related hospitalizations in Chile between 1994 and 2007. Among the serotypes identified, "other" or "non-vaccine serotypes within vaccine serogroups" (which included Spn19A) were reported for 72 patients with invasive clinical syndromes. For these patients, the case fatality rate was $0 \%$. The

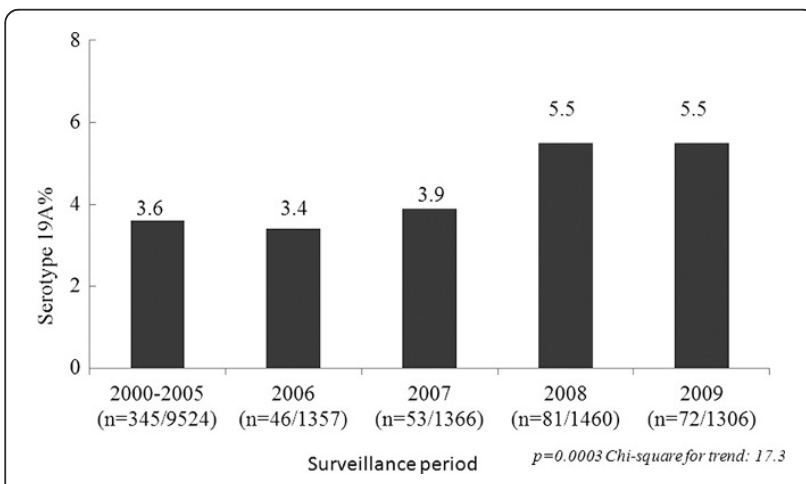

Figure 2 Streptococcus pneumoniae serotype 19A distribution of invasive isolates SIREVA data, 2000-2005, 2006, 2007, 2008, 2009.
Table 4 Streptococcus pneumoniae serotype 19A isolates from acute otitis media and nasopharyngeal - healthy and sick children

\begin{tabular}{|c|c|c|c|c|}
\hline \multirow[t]{2}{*}{ Country [Reference] } & \multirow{2}{*}{$\begin{array}{l}\text { Year of } \\
\text { isolate }\end{array}$} & \multicolumn{2}{|c|}{ Serotype 19A } & \multirow{2}{*}{$\frac{\text { Total }}{n}$} \\
\hline & & $\mathrm{n}$ & $\%$ & \\
\hline \multicolumn{5}{|l|}{ Acute Otitis Media } \\
\hline Brazil [35] & 1990-1995 & 6 & 12.5 & 48 \\
\hline Colombia [36] & 2008-2009 & 1 & 2.8 & 36 \\
\hline Costa Rica [37] & 1992-2007 & 2 & 0.6 & 346 \\
\hline Mexico [38] & $1995-2000$ & 5 & 16.7 & 30 \\
\hline Total & & 11 & 2.4 & 460 \\
\hline \multicolumn{5}{|c|}{ Nasopharyngeal isolates - Healthy children } \\
\hline Argentina [39] & 2000-2007 & 27 & 3.7 & 728 \\
\hline Brazil [40] & 1998 & 1 & 0.7 & 135 \\
\hline Brazil [41] & 2000 & 10 & 4.5 & 222 \\
\hline Brazil [42] & $2000-2001$ & 1 & 3.0 & 33 \\
\hline Brazil [43] & 2005 & 21 & 6.3 & 332 \\
\hline Chile [44] & 1994-1999 & 0 & 0.0 & 68 \\
\hline Chile [45] & 1994-1995 & 5 & 10.0 & 50 \\
\hline Chile [46] & 2001-2003 & 16 & 2.2 & 714 \\
\hline Colombia [47] & 2009 & 6 & 3.5 & 170 \\
\hline Mexico [48] & 1994 & 4 & 6.2 & 65 \\
\hline Mexico [38] & 1997-2000 & 6 & 3.5 & 173 \\
\hline Mexico [49] & 2002 & 50 & 6.0 & 829 \\
\hline Mexico [50] & 2002-2003 & 0 & 0.0 & 122 \\
\hline Mexico [51] & 2006 & 19 & 10.8 & 176 \\
\hline Panama [52] & 2008 & 2 & 1.2 & 163 \\
\hline Peru [53] & 2000 & 3 & 2.1 & 146 \\
\hline Uruguay [54] & 1993-1995 & 3 & 4.1 & 74 \\
\hline Venezuela [55] & 2004-2005 & 5 & 4.1 & 122 \\
\hline Venezuela [56] & 2008 & 1 & 1.7 & 58 \\
\hline Total & & 180 & 4.1 & 4380 \\
\hline \multicolumn{5}{|c|}{ Nasopharyngeal isolates - Sick children } \\
\hline Brazil [57] & 1997 & 3 & 1.9 & 162 \\
\hline Brazil [58] & $2002-2003$ & 1 & 8.3 & 12 \\
\hline Brazil [59] & 2009 & 7 & 9.9 & 71 \\
\hline Mexico [48] & 1994 & 5 & 7.2 & 69 \\
\hline Uruguay [54] & 1993-1995 & 0 & 0.0 & 21 \\
\hline Venezuela [60] & 2000 & 0 & 0.0 & 27 \\
\hline Total & & 16 & 4.4 & 362 \\
\hline
\end{tabular}

annual incidence of IPD among children 0-59 months of age caused by Spn19A was 1 per 100,000.

In Córdoba, Argentina, Tregnaghi et al. [27] found a highest incidence of IPD $(206 / 100,000$ children $<2$ years old), attributed to ambulatory patients. No Spn19A isolates were isolated. 
Table 5 Streptococcus pneumoniae serotype 19A, penicillin resistance, SIREVA data 2007-2009

\begin{tabular}{|c|c|c|c|c|c|c|c|c|}
\hline \multirow{5}{*}{$\begin{array}{l}\text { Years } \\
\text { [23] }\end{array}$} & \multicolumn{8}{|c|}{ Streptococcus pneumoniae 19A } \\
\hline & \multicolumn{3}{|c|}{ Meningitis } & \multicolumn{5}{|c|}{ Non-meningitis } \\
\hline & \multirow{2}{*}{\multicolumn{2}{|c|}{$\begin{array}{c}\text { PNSP } \\
\text { resistant }^{a}\end{array}$}} & \multirow[t]{3}{*}{ Total } & \multicolumn{4}{|c|}{ PNSP } & \multirow[t]{3}{*}{ Total } \\
\hline & & & & \multicolumn{2}{|c|}{ Intermediate $^{b}$} & \multicolumn{2}{|c|}{ High $^{b}$} & \\
\hline & $\mathrm{n}$ & $\%$ & & $n$ & $\%$ & $\mathrm{n}$ & $\%$ & \\
\hline 2007 & 8 & 57.1 & 14 & $2^{c}$ & 5.1 & 0 & 0.0 & 39 \\
\hline 2008 & 9 & 64.3 & 14 & $6^{d}$ & 9.4 & $3^{d}$ & 4.7 & 64 \\
\hline 2009 & 5 & 38.5 & 13 & $9^{e}$ & 16.4 & $2^{e}$ & 3.6 & 55 \\
\hline Total & 22 & 53.7 & 41 & 17 & 10.8 & 5 & 3.2 & 158 \\
\hline
\end{tabular}

${ }^{\mathrm{a}} \mathrm{CLSI}$ 2010, Penicillin-Nonsusceptible S. pneumoniae (PNSP) resistant $\geq 0.125 \mu \mathrm{g} / \mathrm{ml}$ [61]. ${ }^{\mathrm{b}} \mathrm{CLSI} 2010$, PNSP intermediate resistance $(\mathrm{IR})=4.0 \mu \mathrm{g} / \mathrm{ml}$, PNSP high resistance $(\mathrm{HR}) \geq 8.0 \mu \mathrm{g}[61]$.

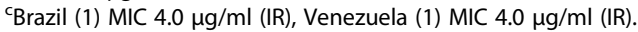

${ }^{\mathrm{d} B r a z i l}(2)$, MIC $4.0 \mu \mathrm{g} / \mathrm{ml}$ (IR); Venezuela (2), MIC $4.0 \mu \mathrm{g} / \mathrm{ml}$ (IR); Chile(1), MIC $4.0 \mu \mathrm{g} / \mathrm{ml}$ (IR); Mexico (1), MIC $4.0 \mu \mathrm{g} / \mathrm{ml}$ (IR); Peru (2), MIC $\geq 8.0 \mu \mathrm{g} / \mathrm{ml}(\mathrm{HR})$; Colombia (1), MIC $\geq 8.0$ (HR).

${ }^{e}$ Chile (2), MIC $4.0 \mu \mathrm{g} / \mathrm{ml}$ (IR); Colombia (2), MIC $4.0 \mu \mathrm{g} / \mathrm{ml}$ (IR); Cuba (1), MIC $4.0 \mu \mathrm{g} / \mathrm{ml}$ (IR); Dominican Republic (1), MIC $4.0 \mu \mathrm{g} / \mathrm{ml}$ (IR); Mexico (5) $3 \mathrm{MIC}$ $4.0 \mu \mathrm{g} / \mathrm{ml}(\mathrm{IR})$ and $2 \mathrm{MIC} \geq 8.0 \mu \mathrm{g} / \mathrm{ml}(\mathrm{HR})$.

Pneumococcal vaccine potential impact for invasive disease With the SIREVA data for IPD the estimated percentage was $63 \%$ for PCV7, $79.3 \%$ for PCV10, and $85.5 \%$ for PCV13. We carried out an analysis to establish the potential benefit of adding Spn19A, 1 and 5. This showed that addition of serotypes 1 and 5 increase impact by $13.2 \%$, whilst addition of $19 \mathrm{~A}$ increases vaccine impact by $4 \%$ (see Additional file 10).

\section{Discussion}

This systematic review of Spn19A data in children under 6 years old, from studies conducted in LAC over a period of 20 years shows that Spn19A remains a less common agent of IPD than other serotypes (3.8\%), ranking $9^{\text {th }}$ in the twenty most prevalent serotypes [23]. The percentage of isolates accounted by Spn19A differed between countries, being the $10^{\text {th }}$ most frequently reported from Colombia, the $6^{\text {th }}$ from Mexico and 4th from Venezuela (Additional file $3 \mathrm{a}$ and Additional file 11). This information provides a complete overview of the role of Spn19A for pneumococcal disease facilitating the decision process for those countries considering to introduce PCV, but also will allow evaluation of potential variations in the prevalence of Spn19A and other serotypes, as reported previously in studies following introduction of PCV7 [14-19,23].

Our analysis of the literature identified the serotypes accounting for $85.4 \%$ of IPD in the region, serotype 14 being the most common (28.7\%). However, the percentage of isolates accounted for by each of these serotypes varied from country to country, in agreement with Johnson's observation in her recent global serotype paper [4].
The scope of our search strategy allowed us to retrieve comprehensive lists of peer-reviewed publications. Two of our authors being members of the SIREVA team, we were able to identify the vast majority of relevant publications in non-indexed journals and obtain personal communications with SIREVA coordinators [23]. Additionally, information retrieved from over a 20 year period evaluated secular trends and the periodicity of serotypes described in the literature [1-4].

A strength of our analysis is that the percentage of IPD Spn19A isolates reported in the non SIREVA data that we reviewed (7 reports, 1990-2008) was not significantly different from that for the SIREVA data (3.8\%).

Regarding time period of Spn19A prevalence, a significant increase, from $3.3 \%$ to $4.6 \%$, was noted only in Argentina and Colombia between 1994-1999 and 2006-2009 before any universal vaccine intervention could have had an impact. However, Spn19A stability was observed in Brazil, Chile, Dominican Republic and Mexico. Similar increases in the percentage of isolates accounted for Spn19A, even prior to the introduction of PCV7, have been reported in Europe [63], South Korea [64], Southern Israel [65] and Taiwan [66], likely reflecting selection pressure from antibiotic use.

On the other hand, in the USA the observed increasing prevalence of PRSP and MDR Spn19A has been suggested to be due to a rapid expansion of the Spn19A clonal complex CC320, to more than one new clone introduced or to successful clones associated with other serotypes that have undergone a recombinational switch to Spn19A [20,21].

In the LAC region only one study, describing PFGE patterns of Spn19A isolates, and conducted in Colombia [67], reported Spn19A MDR isolates in IPD; two were found related to the clone Colombia ${ }^{23 F}-S T 338$, one to the clone Spain ${ }^{23 F}$-ST81, and 6 were not related to the clones studied. A possible explanation of these findings may be that a successful clone, such as Spain ${ }^{23 F}$, underwent a recombinational switch to Spn19A.

No differences could be established between age groups for the prevalence of Spn19A as an IPD agent. In contrast, serotypes 1 and 5 were more frequent in children 2-5 years old and serotypes $6 \mathrm{~B}$ and 14 were more frequent in $<2$ year olds than in the other age groups in the LAC region (See Additional file 5).

Our analysis suggests that Spn19A causing IPD in LAC is more frequently an agent of non-meningitis disease $(4.5 \%$ of cases), in particular pneumonia than of meningitis (2.9\%) (See Additional file 6a).

PNSP in invasive Spn19A isolates has been reported in LAC since 1993 [26]. A study conducted in 2010, using the new CLSI breakpoints for penicillin [61], showed that resistant Spn19A isolates are circulating in the region, more frequently as agents of meningitis $(\mathrm{MIC} \geq 0.125 \mu \mathrm{g} / \mathrm{ml})$ than for of non-meningitis (MIC $\geq 4.0 \mu \mathrm{g} / \mathrm{ml}$ ). However, 


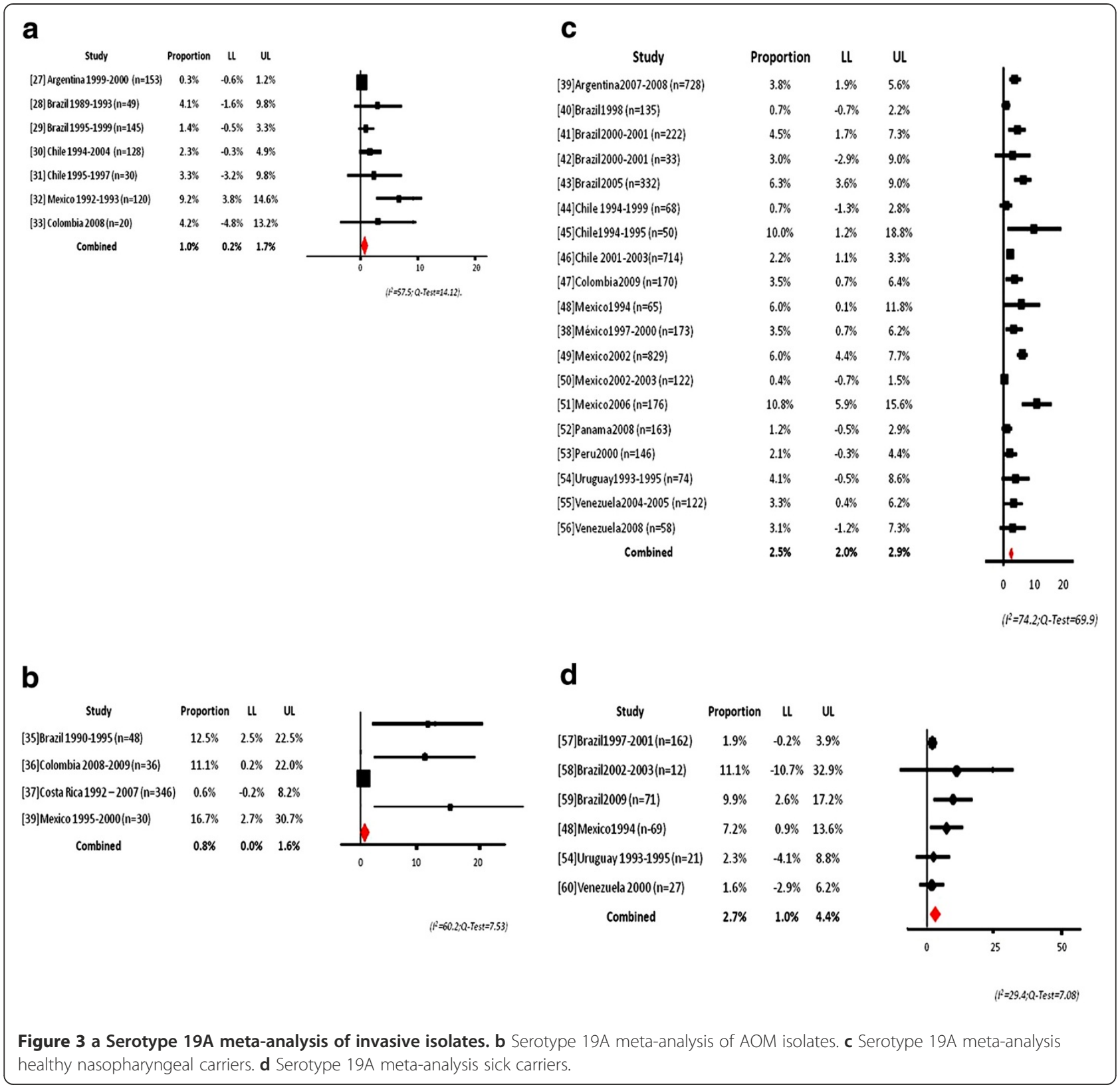

the finding of a prevalence of $3.2 \%$ for Spn19A with $\mathrm{MIC} \geq 8.0 \mu \mathrm{g} / \mathrm{ml}$ among non-meningitis cases, recovered in Mexico, Colombia and Venezuela is of great concern, as it follows reports of $7.7 \%$ of cases being attributed to serotype 19F. Molecular surveillance data will reveal their role as agents of pneumococcal disease [20,21].

Despite the fact that S. pneumoniae causes $30-60 \%$ of AOM cases worldwide [68], only three papers and one abstract were found and analyzed; overall, $2.4 \%$ of these were attributed to Spn19A. As AOM continues to be an important childhood infection and given that the etiology might change from VT to non-PCV7 strains once pneumococcal vaccines are widely implemented [69], it is important to conduct AOM etiology studies in the region. S. pneumoniae may be subject to serotype replacement phenomena and attention to antibiotic resistant NVT otopathogens as well as non typable Haemophilus influenzae is required [70].

Nasopharyngeal carriage has been confirmed with greater values reported for children less than 5 years old. From the papers analyzed, Spn19A ranked the $6^{\text {th }}$ most frequently reported serotype for healthy children (4.1\%), jointly with Non-Typable. There were a high number of serotypes with ability for colonizing the nasopharynx, with serotype $19 \mathrm{~F}$ the most frequently identified (See Additional file 7b).

Nasopharyngeal serotypes described in Latin America from 1994 to 2008 are very similar to those described by 


\begin{tabular}{|c|c|c|c|c|}
\hline \multirow{3}{*}{ Condition } & \multicolumn{4}{|c|}{ Range expressed in cases per $100,000 /$ year } \\
\hline & \multicolumn{4}{|c|}{ Age group (years) } \\
\hline & $<1$ & $<2$ & $<3$ & $<5$ \\
\hline $\begin{array}{l}\text { Invasive } \\
\text { pneumococcal } \\
\text { disease IPD }\end{array}$ & $61(58-63)^{a}$ & $61(52-71)$ & & $32(32-33)$ \\
\hline $\begin{array}{l}\text { S. pneumoniae 19A } \\
\text { specific incidence }^{\text {b }}\end{array}$ & $2.3(2.2-2.9)$ & $2.8(2.4-3.3)$ & & \\
\hline $\begin{array}{l}\text { Pneumococcal } \\
\text { meningitis }\end{array}$ & 19 & 12 & & $11(9-15)$ \\
\hline $\begin{array}{l}\text { S. pneumoniae 19A } \\
\text { specific incidence }^{c}\end{array}$ & 0.6 & 0.4 & & $0.3(0.27-0.45)$ \\
\hline $\begin{array}{l}\text { Pneumococcal } \\
\text { pneumonia }\end{array}$ & & $51(47-55)$ & & 34 \\
\hline $\begin{array}{l}\text { S. pneumoniae 19A } \\
\text { specific incidence }^{d}\end{array}$ & & $1.98(1.8-2.1)$ & & 1.3 \\
\hline Pneumococcal sepsis & & 12 & & \\
\hline $\begin{array}{l}\text { S. pneumoniae 19A } \\
\text { specific incidence }\end{array}$ & & 0.6 & & \\
\hline $\begin{array}{l}\text { Pneumococcal } \\
\text { bacteremia }\end{array}$ & & & 2 & \\
\hline $\begin{array}{l}\text { S. pneumoniae 19A } \\
\text { specific incidence }^{4}\end{array}$ & & & 0.2 & \\
\hline
\end{tabular}

(Adapted from reference [62]).

a (25th-75th percentile, when reported).

b S. pneumoniae 19A distribution reported in SIREVA 1993-2009 $=3.8 \%$.

' S. pneumoniae 19A distribution reported in SIREVA 2000-2009 $=3.0 \%$.

${ }^{d}$ S. pneumoniae 19A distribution reported in SIREVA 2006-2007 $=3.9 \%$.

e S. pneumoniae 19A distribution reported in SIREVA 2000-2009 $=4.6 \%$.

Huang in 2001 (pre vaccine data) for generally healthy children in 16 Massachusetts communities. Spn19A represented $4.2 \%$ of 143 isolates; PNSP was described for $77 \%$ of the NVT, in particular for serotypes 6A, 19A and 9A [12].

Studies conducted since the introduction of PCV7 vaccination have shown decreases in colonization with pneumococcal VT shortly after immunization as well as longer-term changes in colonization patterns. Huang [12] reported a decrease in the carriage of VT from $36 \%$ to $3 \%$ seven years after mass introduction of PCV7, whereas NVT carriage increased from $15 \%$ to $29 \%$. The common colonizing serotypes in 2007 included 19A (16\%) (Baseline data 6.0\%), 6A (12\%), 15B/C (11\%), 35B $(9 \%)$ and $11 \mathrm{~A}(8 \%)$, a clear reflection of the replacement phenomenon. Additionally, the more frequent colonizing serotypes have greater resistance to penicillin. Nasopharyngeal surveillance appears to be a reliable system for measuring vaccination impact in terms of a decrease in VT types and will help to elucidate the emergence of NVT following PCV introduction.

Incidence rates reported by Lagos [46] for IPD caused by Spn19A ranged from 0.4 to 2.2 cases $\mathrm{x} 100,000$ between 1994 and 2007, suggesting a seasonal pattern for this serotype. Similar variations have been shown for other serotypes in the LAC region, such as 1 and 5 [34] and may explain changes during time periods in the SIREVA data presented in this review. This should be considered when interpreting data post introduction of pneumococcal vaccines in this region. In contrast, the incidence of other serotypes such as 14 has shown small variations [26,34].

PCVs have been introduced recently in several countries in LAC, but currently, there are no data published about their impact in reducing IPD. Consequently, little is known about the replacement phenomenon with Spn19A, which has been well described previously [22]. Available data provide only an estimation of hypothetical impact (supplement 10). The same calculation for the recent SIREVA data [4] showed a major impact of PCV10 and PCV13 vaccination, in particular related to the inclusion of serotypes 1 and 5. In fact, after 2009, countries in the region have incorporated different $\mathrm{PCV}$ into their expanded program of immunization following individual assessment for their epidemiology (PCV7/13: Costa Rica, Uruguay, Mexico and PCV-10: Brazil, Colombia, Ecuador and Chile). Following the results of this review, indicating the low prevalence of Spn19A in most of the countries, it is necessary to report any subsequent change in the distribution of this serotype in those countries who have introduced one of the available PCV. Particularly, trying to explain any increase or decrease in the Spn19A prevalence comparing the statistics prior to universal vaccination and possible factors that could explain this, such as vaccine coverage, antibiotic use and immune response based on the vaccine formulation.

The results of our systematic review have a number of limitations. The source of primary data, either from SIREVA or from independent research teams, could introduce selection bias, potentially promoting the selection of more severe forms of the disease. However, it is important to highlight that more severe disease will have the largest impact from a burden of disease or a public health perspective. Information on disease severity caused by Spn19A in this region was limited; this is also the case for data collected for other serotypes, given that similar surveillance activities are employed in the different countries. As this limitation is not restricted to a specific serotype, it should not bias our conclusions. It was not possible to analyze temporal changes in serotype frequency, except from a very broad perspective. The small amount of data available on burden of disease and on the possible effects of mass vaccination highlights the need for more research in this area.

Incidence of IPD in this region ranges from 3.0 to 206.8 cases per 100,000. Overall 9 serotypes are responsible for $80 \%$ of IPD and $30 \%$ are due to serotype 14; Spn19A remains relatively uncommon as an agent of 
IPD, with the exception of Mexico and Venezuela. Data on noninvasive disease and nasopharyngeal carriage, although not as robust, show the same low prevalence.

\section{Conclusions}

As several countries in the region implemented PCV in their routine schedules starting in 2006, regional data on vaccination impact on IPD, non invasive and nasopharyngeal carriage by VT and herd effect should soon be available. In the near future we expect that data on VT and NVT, supported by a solid surveillance system, will be available, which will support public health decisions on the introduction of PCV.

\section{Additional files}

Additional file 1: a- Streptococcus pneumoniae serotype 19A, search strategies. b - Streptococcus pneumoniae definitions.

Additional file 2: Characteristics of the 63 studies included in the analysis, SIREVA and non SIREVA [2,27-60,62,71-135].

Additional file 3: a- Streptococcus pneumoniae. Number of invasive isolates by serotype and country presented by vaccine type (VT) (PCV7, PCV10, PCV13) and non vaccine type (NVT). SIREVA, 1993-2009 and non SIREVA, 1989-2008. b - Streptococcus pneumoniae. Serotypes invasive isolates, $<6$ years old, SIREVA, 20 countries*, 2000-2005. c - Streptococcus pneumoniae. Serotypes invasive isolates, $<5$ years old, SIREVA, 20 countries*, 2006-2009 [27-33,75,82,85,86,89,97].

Additional file 4: Streptococcus pneumoniae, serotype prevalence in three time periods of SIREVA results presented by vaccine type (VT) (PCV7, PCV10, PCV13) and non vaccine type (NVT). [75,82,85,86,89,97].

Additional file 5: Streptococcus pneumoniae. Serotype distribution for invasive isolates by age group $<2$ years and $2-5$ years. SIREVA data, 2007-2009 [86,89,97].

Additional file 6: a- Streptococcus pneumoniae serotype 19A. Meningitis, non-meningitis in ten countries. SIREVA data, 2000-2009. b Streptococcus pneumoniae serotype 19A. Non-meningitis and pneumoniae cases in 20 countries. SIREVA data, 2006-2007. c - Streptococcus pneumoniae. Meningitis isolates by country and serotype presented by vaccine type (VT) (PCV7, PCV10, PCV13) and non vaccine type (NVT). SIREVA data, 2000-2009. d - Streptococcus pneumoniae. Non-meningitis isolates by country and serotype presented by vaccine type (VT) (PCV7, PCV10, PCV13) and non vaccine type (NVT). SIREVA data, 2000-2009 [34,82,85,86,89,97].

Additional file 7: a- Streptococcus pneumoniae. Number of acute otitis media isolates presented by vaccine type (VT) (PCV7, PCV10, PCV13) and non vaccine type (NVT). b - Streptococcus pneumoniae. Number of nasopharyngeal isolates in healthy children presented by vaccine type (VT) (PCV7, PCV10, PCV13) and non vaccine type (NVT). C - Streptococcus pneumoniae. Number of nasopharyngeal isolates in sick children presented by vaccine type (NT) (PCV7, PCV10, PCV13) and non vaccine type (NVT) [35-60,76].

Additional file 8: a- Streptococcus pneumoniae. Meningitis and non-meningitis isolates, penicillin resistance by serotype. SIREVA data 2007-2009. b - Streptococcus pneumoniae serotype 19A. Meningitis isolates, penicillin resistance. Argentina, Brazil, Colombia, Mexico and Venezuela. 2007$2009[86,89,97]$.

Additional file 9: Pneumococcal diseases in Latin America and the Caribbean incidences by country $[27,29,33,46,77-79,83,134,135]$.

Additional file 10: Pneumococcal vaccines. Hypothetical vaccine impact, population $<6$ years $[27-30,32-36,40-42,46,49,50,55,56,58,74,75,82,85-$ $90,97,108,112,113,117,119,123,129]$.

Additional file 11: Streptococcus pneumoniae serotype 19A prevalence in the region. SIREVA data 2000-2009.

\section{Competing interests}

Elizabeth Castañeda, Clara Inés Agudelo, Diego Rosselli and Claudia Calderón no conflicts to declare.

Rodrigo De Antonio, Eduardo Ortega-Barria and Romulo E Colindres are employees of GlaxoSmithKline Biologicals.

Eduardo Ortega-Barria and Rómulo E Colindres have stock ownership: Rodrigo DeAntonio has stock options.

\section{Authors' contributions}

EC contributed to systematic review conception and design, data analysis, interpretation of data, elaboration, review and comments on all drafts of this paper and gave final approval to submit for publication. CIA contributed to systematic review conception and design, data analysis, interpretation of data, elaboration, review and comments on all drafts of this paper and gave final approval to submit for publication. RDA contributed to systematic review conception and design, data analysis, interpretation of data, review and comments on all drafts of this paper and gave final approval to submit for publication. DR contributed to systematic review conception and design, data analysis, interpretation of data, review and comments on all drafts of this paper and gave final approval to submit for publication. CC contributed to systematic review conception and design, data analysis, interpretation of data, review and comments on all drafts of this paper and gave final approval to submit for publication. EO-B contributed to systematic review conception and design, interpretation of data, review and comments on all drafts of this paper and gave final approval to submit for publication. REC contributed to systematic review conception and design, interpretation of data, review and comments on all drafts of this paper and gave final approval to submit for publication. All authors read and approved the final manuscript.

\section{Acknowledgements}

Authors would like to thank Juliette Gray (XPE Pharma \& Science, on behalf of GlaxoSmithKline) for her valuable contribution in editorial support. GlaxoSmithKline Biologicals funded the study.

\section{Author details}

${ }^{1}$ Instituto Nacional de Salud Bogotá, Bogotá, Colombia. ${ }^{2}$ GlaxoSmithKline Biologicals, Panama City, Panama. ${ }^{3}$ Department of Clinical Epidemiology and Biostatistics, Universidad Javeriana Medical School, Bogotá, Colombia. ${ }^{4}$ Independent investigator, Bogotá, Colombia. ${ }^{5} \mathrm{GlaxoS}$ ithKline Biologicals, Rio de Janeiro, Brazil. ${ }^{6} \mathrm{GlaxoS}$ mithKline Biologicals, Wavre, Belgium.

Received: 3 October 2011 Accepted: 27 March 2012

Published: 28 May 2012

\section{References}

1. Lynch JP 3rd, Zhanel GG: Streptococcus pneumoniae: epidemiology and risk factors, evolution of antimicrobial resistance, and impact of vaccines. Curr Opin Pulm Med 2010, 16:217-225.

2. O'Brien $\mathrm{KL}$, Wolfson $L$, Watt JP, Henkle E, Deloria-Knoll M, McCall N, Lee E, Mulholland K, Levine OS, Cherian T, Hib and Pneumococcal Global Burden of Disease Team: Burden of disease caused by Streptococcus pneumoniae in children younger than 5 years: global estimates. Lancet 2009, 374:893902.

3. Levine OS, Knoll MD, Jones A, Walker DG, Risko N, Gilani Z: Global status of Haemophilus influenzae type $b$ and pneumococcal conjugate vaccines: evidence, policies, and introductions. Curr Opin Infect Dis 2010, 23:236-241.

4. Johnson HL, Deloria-Knoll M, Levine OS, Stoszek SK, Freimanis Hance L, Reithinger R, Muenz LR, O'Brien KL: Systematic evaluation of serotypes causing invasive pneumococcal disease among children under five: the pneumococcal global serotype project. PLoS Med 2010, 7:e1000348. doi:10.1371/journal.pmed.1000348.

5. Satzke C, Ortika BD, Oftadeh S, Russell FM, Robins-Browne RM, Mulholland EK, Gilbert GL: Molecular epidemiology of Streptococcus pneumoniae serogroup 6 isolates from Fijian children, including newly identified serotypes 6C and 6D. J Clin Microbiol 2010, 48:4298-4300.

6. Calix JJ, Nahm MH: A new pneumococcal serotype, $11 \mathrm{E}$, has a variably inactivated wcjE gene. J Infect Dis 2010, 202:29-38.

7. Pneumococcal Molecular Epidemiology Network (PMEN). Clone Collection. [http://www.sph.emory.edu/PMEN/pmen_clone_collection.html] 
8. Whitney CG, Farley MM, Hadler J, Harrison LH, Bennett NM, Lynfield R, Reingold A, Cieslak PR, Pilishvili T, Jackson D, Facklam RR, Jorgensen JH, Schuchat A: Active bacterial core surveillance of the emerging infections program network. Decline in invasive pneumococcal disease after introduction of protein-polysaccharide conjugate vaccine. New Engl J Med 2003, 348:1737-1746.

9. Kyaw MH, Lynfield R, Schaffner W, Craig AS, Hadler J, Reingold A, Thomas AR, Harrison LH, Bennett NM, Farley MM, Facklam RR, Jorgensen JH, Besser J, Zell ER, Schuchat A, Whitney CG: Active bacterial core surveillance of the emerging infections program network. Effect of introduction of the pneumococcal conjugate vaccine on drug-resistant Streptococcus pneumoniae. N Engl J Med 2006, 354:1455-1463. Erratum in, N Engl J Med.

10. Hsu HE, Shutt KA, Moore MR, Beall BW, Bennett NM, Craig AS, Farley MM, Jorgensen JH, Lexau CA, Petit S, Reingold A, Schaffner W, Thomas A, Whitney CG, Harrison LH: Effect of pneumococcal conjugate vaccine on pneumococcal meningitis. N Engl J Med 2009, 360:244-256.

11. Pilishvili T, Lexau C, Farley MM, Hadler J, Harrison LH, Bennett NM, Reingold A, Thomas A, Schaffner W, Craig AS, Smith PJ, Beall BW, Whitney CG, Moore MR: Active bacterial core surveillance/emerging infections program network. Sustained reductions in invasive pneumococcal disease in the era of conjugate vaccine. J Infect Dis 2010, 201:32-41.

12. Huang SS, Hinrichsen VL, Stevenson AE, Rifas-Shiman SL, Kleinman K, Pelton SI, Lipsitch M, Hanage WP, Lee GM, Finkelstein JA: Continued impact of pneumococcal conjugate vaccine on carriage in young children. Pediatrics 2009, 124:e1-e11.

13. Pulido M, Sorvillo F: Declining invasive pneumococcal disease mortality in the United States, 1990-2005. Vaccine 2010, 28:889-892.

14. Pelton $\mathrm{Sl}$, Huot $\mathrm{H}$, Finkelstein JA, Bishop CJ, Hsu KK, Kellenberg J, Huang SS, Goldstein R, Hanage WP: Emergence of 19A as virulent and multidrug resistant pneumococcus in Massachusetts following universal immunization of infants with pneumococcal conjugate vaccine. Pediatr Infect Dis J 2007, 26:468-472

15. Pichichero ME, Casey JR: Emergence of a multiresistant serotype 19A pneumococcal strain not included in the 7-valent conjugate vaccine as an otopathogen in children. JAMA 2007, 298:1772-1778,

16. Hicks LA, Harrison LH, Flannery B, Hadler JL, Schaffner W, Craig AS, Jackson D, Thomas A, Beall B, Lynfield R, Reingold A, Farley MM, Whitney CG: Incidence of pneumococcal disease due to non-pneumococcal conjugate vaccine (PCV7) serotypes in the United States during the era of widespread PCV7 vaccination, 1998-2004. J Infect Dis 2007, 196:1346-1354.

17. Gertz RE Jr, Li Z, Pimenta FC, Jackson D, Juni BA, Lynfield R, Jorgensen JH, Carvalho Mda G, Beall BW, Active Bacterial Core Surveillance Team: Increased penicillin nonsusceptibility of nonvaccine-serotype invasive pneumococci other than serotypes $19 \mathrm{~A}$ and $6 \mathrm{~A}$ in post-7-valent conjugate vaccine era. J Infect Dis 2010, 201:770-775.

18. Techasaensiri C, Messina AF, Katz K, Ahmad N, Huang R, McCracken GH Jr: Epidemiology and evolution of invasive pneumococcal disease caused by multidrug resistant serotypes of $19 \mathrm{~A}$ in the 8 years after implementation of pneumococcal conjugate vaccine immunization in Dallas, Texas. Pediatr Infect Dis J 2010, 29:294-300.

19. Kaplan SL, Barson WJ, Lin PL, Stovall SH, Bradley JS, Tan TQ, Hoffman JA, Givner LB, Mason EO Jr: Serotype 19A is the most common serotype causing invasive pneumococcal infections in children. Pediatrics 2010, 125:429-436.

20. Moore MR, Gertz RE Jr, Woodbury RL, Barkocy-Gallagher GA, Schaffner W, Lexau C, Gershman K, Reingold A, Farley M, Harrison LH, Hadler JL, Bennett NM, Thomas AR, McGee L, Pilishvili T, Brueggemann AB, Whitney CG, Jorgensen JH, Beall B: Population snapshot of emergent Streptococcus pneumoniae serotype 19A in the United States, 2005. J Infect Dis 2008, 197:1016-1027.

21. Pillai DR, Shahinas D, Buzina A, Pollock RA, Lau R, Khairnar K, Wong A, Farrell DJ, Green K, McGeer A, Low DE: Genome-wide dissection of globally emergent multi-drug resistant serotype 19A Streptococcus pneumoniae. BMC Genomics 2009, 10:642. doi:10.1186/1471-2164-10-642.

22. Reinert R, Jacobs MR, Kaplan SL: Pneumococcal disease caused by serotype 19A: review of the literature and implications for future vaccine development. Vaccine 2010, 28:4249-4259.

23. Pan American Health Organization. PAHO: SIREVA II (Sistema de Redes de Vigilancia de los Agentes Responsables de Neumonías y Meningitis Bacterianas). [http://new.paho.org/hq/index.php?option=com content\&task=blogcategory\&id=3609\&ltemid=3953]
24. Stroup DF, Berlin JA, Morton SC, Olkin I, Williamson GD, Rennie D, Moher D, Becker BJ, Sipe TA, Thacker SB: Meta-analysis of observational studies in epidemiology: a proposal for reporting. JAMA 2000, 283:2008-2012.

25. Shrout P, Fleiss J: Intraclass correlations: uses in assessing rater reliability. Psychological Bulletin 1979, 86:420-428.

26. Di Fabio JL, Castañeda E, Agudelo Cl, De La Hoz F, Hortal M, Camou T, Echániz-Avilés G, Noemi M, Barajas C, Heitmann I, Hormazabal JC, Brandileone MC, Dias Vieira VS, Regueira M, Ruvinski R, Corso A, Lovgren M, Talbot JA, De Quadros C: Evolution of Streptococcus pneumoniae serotypes and penicillin susceptibility in Latin America, Sireva-Vigía Group, 1993 to 1999. Pediatr Infect Dis J 2001, 20:959-967.

27. Tregnaghi M, Ceballos A, Ruttimann R, Peeters P, Tregnaghi JP, Ussher J, Rodriguez M, Carvajal L, Yudowski S, Bortolin A, De Lisa I, Oller Robledo H: Vigilancia epidemiológica activa de la enfermedad neumocócica en lactantes, en el ámbito ambulatorio y en la internación. Arch Argent Pediatr 2006, 104:3-9.

28. Berezin EN, Carvalho ES, Casagrande S, Brandileone MC, Mimica IM, Farhat CK Streptococcus pneumoniae penicillin-nonsusceptible strains in invasive infections in Sao Paulo, Brazil. Pediatr Infect Dis J 1996, 15:1051-1053.

29. Reis JN, Cordeiro SM, Coppola SJ, Salgado K, Carvalho MG, Teixeira LM, Thompson TA, Facklam RR, Reis MG, Ko Al: Population-based survey of antimicrobial susceptibility and serotype distribution of Streptococcus pneumoniae from meningitis patients in Salvador, Brazil. J Clin Microbiol 2002, 40:275-277.

30. Inostroza J, Illesca V, Reydet P, Vinet AM, Ossa G, Muñoz S, Thompson T, Sorensen RU: Ten-year surveillance of pneumococcal infections in Temuco, Chile: implications for vaccination strategies. Clin Vaccine Inmunol 2007, 14:660-664.

31. Inostroza J, Trucco O, Prado V, Vinet AM, Retamal G, Ossa G, Facklam RR, Sorensen $\mathrm{RU}$ : Capsular serotype and antibiotic resistance of Streptococcus pneumoniae isolates in two Chilean cities. Clin Diag Lab Immunol 1998, 5:176-180.

32. Echániz-Aviles G: Capsular Type of Streptococcus pneumoniae causing disease in children from Mexico City. Pediatr Infect Dis J 1995, 14:907-909.

33. Benavides JA, Ovalle OO, Salvador GR, Gray S, Isaacman D, Rodgers GL: Population-based surveillance for invasive pneumococcal disease and pneumonia in infants and young children in Bogotá, Colombia, Presented at: 6th International Symposium on Pneumococci and Pneumococcal Diseases (ISPPD-7). Reykjavik: Islandia; 2008. Available at Vaccine. 2012 Apr 4. [Epub ahead of print].

34. Castañeda $\mathrm{E}$, Agudelo $\mathrm{Cl}$, Regueira $\mathrm{M}$, Corso $\mathrm{A}$, Brandileone MC, Brandão AP, Maldonado A, Hormazabal JC, Martínez IT, Llanes R, Sánchez J, Feris JM, EchanizAviles G, Carnalla-Barajas MN, Terrazas MG, Monroy IH, Chamorro G, Weiler N, Camou T, Gabarrot GG, Spadola E, Payares D, Gabastou JM, Di Fabio JL, de la Hoz F, SIREVA II Group: Laboratory-based surveillance of Streptococcus pneumoniae invasive disease in children in 10 Latin American countries: a SIREVA II project, 2000-2005. Pediatr Infect Dis J 2009, 28:e265-e270.

35. Sih TM: Acute otitis media in Brazilian children: analysis of microbiology and antimicrobial susceptibility. Ann Otol Rhinol Laryngol 2001, 110:662-666.

36. Lopez P, Sierra A, Zapata MA, Vanegas B, Castrejon MM, Deantonio R, Hausdorff WP, Colindres RE: Non-typeable Haemophilus influenzae and Streptococcus pneumoniae: Primary causes of acute otitis media in Colombian children. Presented in 13th International Congress on Infectious Diseases (ICID) 2009, USA. Final abstract number 80.0009. http://ww2.isid.org/ Downloads/14th_ICID_Posters_Day3_73_84.pdf.

37. Abdelnour A, Soley C, Guevara S, Porat N, Dagan R, Arguedas A: Streptococcus pneumoniae serotype 3 among Costa Rican children with otitis media: clinical, epidemiological characteristics and antimicrobial resistance patterns. BMC Pediatrics 2009, 9:52.

38. Gómez-Barreto D, Calderón-Jaimes E, Rodríguez RS, Espinosa LE, Viña-Flores L, Jiménez-Rojas V: Carriage of antibiotic-resistant pneumococci in a cohort of a daycare center. Salud Pública Mex 2002, 44:26-32.

39. Gentile A, Prieto N, Fossati S, Rodriguez M, Sorhouet C, Gagetti P, Moscoloni MA, Lamy P, Regueira M, Corso A, Spn Working Group: Nasopharyngeal carriage (NPC) of S. pneumoniae (Spn) among non vaccinated children during winter-summer seasons: first national study in Argentina, Presented at: 6th Annual Meeting of the World Society for Pediatric Infectious Diseases WSPID. Buenos Aires, Argentina 2009:18-22. http://www.abstractserver.com/ wspid09/planner/sp.php?go=abstract\&action=abstract iplanner\&absno=309.

40. Lucarevschi BR, Baldacci ER, Bricks LF, Bertoli CJ, Teixeira LM, Mendes CM, Oplustil C: Oropharyngeal carriage of Streptococcus pneumoniae by children attending day care centers in Taubate, SP: correlation between 
serotypes and the conjugated heptavalent pneumococcal vaccine. J Pediatr (Rio J) 2003, 79:215-220.

41. Laval CB, de Andrade AL, Pimenta FC, de Andrade JG, de Oliveira RM, Silva SA, de Lima EC, Fabio JL, Casagrande ST, Brandileone MC: Serotypes of carriage and invasive isolates of Streptococcus pneumoniae in Brazilian children in the era of pneumococcal vaccines. Clin Microbiol Infect 2006 12:50-55.

42. Reis JN, Palma T, Ribeiro GS, Pinheiro RM, Ribeiro $C T$, Cordeiro SM, da Silva Filho HP, Moschioni M, Thompson TA, Spratt B, Riley LW, Barocchi MA, Reis MG, Ko Al: Transmission of Streptococcus pneumoniae in an urban slum community. J Infect 2008, 57:204-213.

43. Franco CM, Andrade AL, Andrade JG, Almeida e Silva S, Oliveira CR, Pimenta FC, Lamaro-Cardoso J, Brandão AP, Almeida SC, Calix JJ, Nahm MH, de Cunto Brandileone MC: Survey of nonsusceptible nasopharyngeal Streptococcus pneumoniae isolates in children attending day-care centers in Brazil. Pediatr Infect Dis J 2010, 29:77-79.

44. Gherardi G, Inostroza JS, O'Ryan M, Prado V, Prieto S, Arellano C, Facklam RR, Beal IB: Genotypic survey of recent beta-lactam-resistant pneumococcal nasopharyngeal isolates from asymptomatic children in Chile. J Clin Microbiol 1999, 37:3725-3730.

45. Trucco OA, Prado JV, Inostroza JS, Cabrera JE, Teran RR, Bravo PI, Castillo DL, Bustos VR: Prevalencia de Streptococcus pneumoniae resistente a penicilina en niños que asisten a jardines infantiles en Santiago. Rev Chil Pediatr 1996, 67:195-199.

46. Lagos R, Muñoz A, San Martin O, Maldonado A, Hormazabal JC, Blackwelder WC, Levine MM: Age- and serotype-specific pediatric invasive pneumococcal disease: Insights from systematic surveillance in Santiago, Chile, 1994-2007. J Infect Dis 2008, 198:1809-1817.

47. Parra E, Moreno J, Sanabria O, Eljach V: Detection and serotyping of Streptococcus pneumoniae from nasopharyngeal samples of children using multiplex-PCR before heptavalent pneumococcal vaccination in Popayán Colombia, Presented at: 7th International Symposium on Pneumococci and Pneumococcal Diseases (ISPPD-7) 2010. Tel-Aviv, Israel. http://www. abstractserver.com/isppd2010/planner/sp.php? go=abstract\&action=abstract_iplanner\&absno=512\&lSPPD2010=6f9ter 81ucelvs98apjgo40pe1\&ISPPD2010=6f9ter81ucelvs98apjgo40pe1.

48. Miranda Novales MG, Solorzano Santos F, Guiscafre Gallardo H, Leaños Miranda B, Echaniz Aviles G, Carnalla Barajas MN, Palafox Torres M, Muñoz Hernandez O: Streptococcus pneumoniae: low frequency of penicillin resistance and high resistance to trimethoprim-sulfamethoxazole in nasopharyngeal isolates from children in a rural area in Mexico. Arch Med Res 1997, 28:559-563.

49. Espinosa-de Los Monteros LE, Jiménez-Rojas V, Aguilar-Ituarte F, Cashat-Cruz M, Reyes-López A, Rodríguez-Suárez R, Kuri-Morales P, Tapia-Conyer R, Gómez-Barreto D: Streptococcus pneumoniae isolates in healthy children attending day-care centers in 12 states in Mexico. Salud Pública Mex 2007, 49:249-255.

50. Solórzano-Santos F, Ortiz-Ocampo LA, Miranda-Novales MG, Echániz-Avilés G, Soto-Noguerón A, Guiscafré-Gallardo H: Serotipos prevalentes de Streptococcus pneumoniae colonizadores de nasofaringe, en niños del Distrito Federal. Salud Pública Mex 2005, 47:276-281.

51. Reyna J, Limon AE: High prevalence of serotype 11B of Streptococcus pneumoniae isolated in the nasopharynx of Mexican children. Arch Med Res 2008, 39:629-630.

52. Mendez D, Bolaños R: Nasopharyngeal carriage of Streptococcus pneumoniae in healthy children attending daycare centers in Panama. In Presented at: 6th Annual Meeting of the World Society for Pediatric Infectious Diseases - WSPID. Buenos Aires:; 2009:18-22. http://www.abstractserver.com/ wspid09/planner/sp.php?go=abstract\&action=abstract_iplanner\&absno=271.

53. Cullotta AR, Kalter HD, Delgado J, Gilman RH, Facklam RR, Velapatino B, Coronel J, Cabrera L, Urbina M: Antimicrobial susceptibilities and serotype distribution of Streptococcus pneumoniae isolates from a low socioeconomic area in Lima, Peru. Clinical and Diagnostic Lab Immunol 2002, 9:1328-1331.

54. Palacio R, Camou T, Russi JC, Hortal M, Picon T, Nin M, Quian J: Frequency, type and associated diseases of bacteria and virus in the oropharynx of children born to human immunodeficiency virus-infected mothers. Braz J Infect Dis 1998, 2:128-134.

55. Rivera-Olivero IA, Bogaert D, Bello T, del Nogal B, Sluijter M, Hermans PW, de Waard $\mathrm{JH}$ : Pneumococcal carriage among indigenous Warao children in Venezuela: serotypes, susceptibility patterns, and molecular epidemiology. Clin Infect Dis 2007, 45:1427-1434.

56. Bello González T, Rivera-Olivero IA, Pocaterra L, Spadola E, Araque M, Hermans PWM, De Waard JH: Estado de portador nasofaríngeo de Streptococcus pneumoniae en madres e hijos de la población indígena Panare del estado Bolívar, Venezuela. Rev Argent Microbiol 2010, 42:30-34

57. Berezin EN, Cardenuto MD, Ferreira LL, Otsuka M, Guerra ML, Brandileone MC: Distribution of Streptococcus pneumoniae serotypes in nasopharyngeal carriage and in invasive pneumococcal disease in Sao Paulo, Brazil. Pediatr Infect Dis J 2007, 267:643-645.

58. Fonseca PB, Braga JÁ, Machado AM, Brandileone MC, Farhat CK: Nasopharyngeal colonization by Streptococcus pneumoniae in children with sickle cell disease receiving prophylactic penicillin. J Pediatr (Rio J) 2005, 81:149-154.

59. Azevedo J, Galvão VS, Sant'Anna V, da Matta TF, Cordeiro SM, MG Reis dos, Ko Al, Reis JN, Campos LC: Pneumoccocal carriage profile in Brazilian pediatric patients from the pre-vaccine era. Presented at: 7th International Symposium on Pneumococci and Pneumococcal Diseases (ISPPD-7). Tel-Aviv 2010. http://www.abstractserver.com/isppd2010/planner/sp.php? go=abstract\&action=abstract_iplanner\&absno=503\&lSPPD2010= 6f9ter81 ucelvs98apjgo40pe1\&ISPPD2010=6f9ter81 ucelvs98apjgo40pe1.

60. Quintero B, Araque M: Perfil serológico y antibiotipia de cepas de Streptococcus pneumoniae aisladas de portadores nasales pediátricos. Invest Clin 2006, 47:17-26.

61. Clinical and Laboratory Standards Institute: Performance standards for antimicrobial susceptibility testing; Twentieth Informational Supplement. Wayne: Clinical and Laboratory Standards Institute; 2010. M100-S20.

62. Valenzuela MT, O'Loughlin R, De La Hoz F, Gomez E, Constenla D, Sinha A, Valencia JE, Flannery B, De Quadros CA: The burden of pneumococcal disease among Latin American and Caribbean children: Review of the evidence. Rev Panam Salud Pública 2009, 25:270-279.

63. Hanquet G, Kissling E, Fenoll A, George R, Lepoutre A, Lernout T, Tarragó D, Varon E, Verhaegen J: Pneumococcal serotypes in children in 4 European countries. Emerg Infect Dis 2010, 10:1428-1439.

64. Choi EH, Kim SH, Eun BW, Kim SJ, Kim NH, Lee J, Lee HJ: Streptococcus pneumoniae serotype 19A in children, South Korea. Emerg Infect Dis 2008, 14:275-281.

65. Dagan R, Givon-Lavi N, Leibovitz E, Greenberg D, Porat N: Introduction and proliferation of multidrug-resistant Streptococcus pneumoniae serotype $19 \mathrm{~A}$ clones that cause acute otitis media in an unvaccinated population. J Infect Dis 2009, 199:776-785.

66. Hsieh YC, Lin PY, Chiu CH, Huang YC, Chang KY, Liao CH, Chiu NC, Chuang YC, Chen PY, Chang SC, Liu JW, Yen MY, Wang JH, Liu CY, Lin TY: National survey of invasive pneumococcal diseases in Taiwan under partial PCV7 vaccination in 2007: emergence of serotype 19A with high invasive potential. Vaccine 2009, 27:5513-5518.

67. Hidalgo M, Santos C, Duarte C, Castañeda E, Agudelo Cl: Incremento de la resistencia a eritromicina de Streptococcus pneumoniae Colombia. 19942008. Biomédica 2011, 31:124-131.

68. Rodgers GL, Arquedas A, Cohen R, Dagan R: Global serotype distribution among Streptococcus pneumoniae isolates causing otitis media in children: potential implications for pneumococcal conjugate vaccines. Vaccine 2009, 27:3802-3810.

69. Casey JR, Adlowitz DG, Pichichero ME: New patterns in the otopathogens causing acute otitis media six to eight years after introduction of pneumococcal conjugate vaccine. Pediatr Infect Dis J 2010, 29:304-309.

70. Coker TR, Chan LS, Newberry SJ, Limbos MA, Suttorp MJ, Shekelle PG, Takata GS: Diagnosis, microbial epidemiology, and antibiotic treatment of acute otitis media in children: a systematic review. JAMA 2010, 304:2161-2169.

71. Lopez Bravo I, Sepulveda H, Valdes I: Acute respiratory illnesses in the first 18 months of life. Rev Panam Salud Pública 1997, 1:9-17.

72. Magnus SA, Hambleton IR, Moosdeen F, Serjeant GR: Recurrent infections in homozygous sickle cell disease. Arch Dis Child 1999, 80:537-541.

73. Gómez E, Peguero M, Sánchez J, Castellanos PL, Feris J, Peña C, BrudzinskiLaClaire L, Levine OS: Population-based surveillance for bacterial meningitis in the Dominican Republic: implications for control by vaccination. Epidemiol Infect 2000, 125:549-554.

74. Hortal M, Camou T, Palacio R, Dibarboure H, García A: Ten-year review of invasive pneumococcal diseases in children and adults from Uruguay: 
clinical spectrum, serotypes, and antimicrobial resistance. Int J Infect Dis 2000, 4:91-95.

75. Di Fabio JL, Hortal M, Ruvinsky R, Rossi A, Agudelo Cl, Castañeda E, Brandileone C, Camou T, Palacio R, Echániz-Aviles G: Evolution of Streptococcus pneumoniae serotypes and penicillin susceptibility in Latin America, SirevaVigía Group, 1993 to 1999. Ped Infect Dis J 2001, 20:959-967.

76. Gómez-Barreto D, Rodríguez RS, Calderón Jaimes E, Espinoza LE: Bases fisiopatológicas para la prevención de las infecciones por Streptococcus pneumoniae. Boletín Médico del Hospital Infantil de México 2001, 58:866-878.

77. Weiss D, Coplan P, Guess H: Epidemiology of bacterial meningitis among children in Brazil, 1997-1998. Rev Saúde Pública 2001, 35:249-255.

78. Asturias EJ, Soto M, Menendez R, Ramirez PL, Recinos F, Gordillo R, Holt E, Halsey NA: Meningitis and pneumonia in Guatemalan children: the importance of Haemophilus influenzae type $\mathrm{b}$ and Streptococcus pneumoniae. Rev Panam Salud Pública 2003, 14:377-384

79. Ulloa Gutierrez R, Avila-Aguero ML, Herrera ML, Herrera JF, Arguedas A: Invasive pneumococcal disease in Costa Rican children: a seven year survey. Pediatr Infect Dis J 2003, 22:1069-1074.

80. McGregor D, Barton M, Thomas S, Christie CD: Invasive pneumococcal disease in Jamaican children. Ann Trop Pediatr 2004, 24:33-40.

81. Constenla D: Evaluating the costs of pneumococcal disease in selected Latin American countries. Rev Panam Salud Pública 2007, 22:268-278.

82. Grupo de Trabajo de SIREVA II: Informe Regional de SIREVA II: Organización Panamericana de la Salud. Informe Regional de SIREVA II, 2000-2005: datos por país y por grupo de edad sobre las características de los aislamientos de Streptococcus pneumoniae, Haemophilus influenzae y Neisseria meningitidis en procesos invasivos. (Serie Documentos técnicos. Tecnologías esenciales de salud. THS/EV-2007/002). Washington: OPS; 2007.

83. Hortal M, Estevan M, Iraola I, De Mucio B: A population-based assessment of the disease burden of consolidated pneumonia in hospitalized children under five years of age. Int J Infect Dis 2007, 11:273-277.

84. Constenla DO: Economic impact of pneumococcal conjugate vaccination in Brazil, Chile, and Uruguay. Rev Panam Salud Pública 2008, 24:101-112.

85. Grupo de Trabajo de SIREVA II: Informe Regional de SIREVA II: Organización Panamericana de la Salud. Informe Regional de SIREVA II, 2006: datos por país y por grupo de edad sobre las características de los aislamientos de Streptococcus pneumoniae, Haemophilus influenzae y Neisseria meningitidis en procesos invasivos. (Serie Documentos técnicos. Tecnologías esenciales de salud. THS/EV-2008/001). Washington: OPS; 2008

86. Grupo de Trabajo SIREVA II: Informe Regional de SIREVA II: Organización Panamericana de la Salud. Informe Regional de SIREVA II, 2007: datos por país y por grupo de edad sobre las características de los aislamientos de Streptococcus pneumoniae, Haemophilus influenzae y Neisseria meningitidis en procesos invasivos. (Serie Documentos técnicos. Tecnologías esenciales de salud. THS/EV-2008/003). Washington: OPS; 2008.

87. Mattei SM, Falleiros-Carvalho LH, Cavalcante NJF: Invasive pneumococcal disease in HIV seropositive children and adolescents. J Pediatr (Rio J) 2008, 84:276-280.

88. Constenla D, Sinha A, Valencia JE, Gomez E, de la Hoz F, Valenzuela MT, de Quadros CA: Identifying unit costs for use in regional economic evaluation: an illustrative analysis of childhood pneumococcal conjugate vaccine in Latin America and the Caribbean. Rev Panam Salud Pública 2009, 26:458-468.

89. Grupo de Trabajo de SIREVA II: Informe Regional de SIREVA II: Organización Panamericana de la Salud. Informe Regional de SIREVA II, 2008: datos por país y por grupo de edad sobre las características de los aislamientos de Streptococcus pneumoniae, Haemophilus influenzae y Neisseria meningitidis en procesos invasivos. (Serie Documentos técnicos. Tecnologías esenciales de salud. THS/EV-2009/002). Washington: OPS; 2009.

90. Lagos R, Muñoz A, Espinoza A, Dowes A, Ruttimann R, Colindres R: Costos médicos directos de enfermedades neumocócicas invasoras y neumonías con diagnóstico radiológico en niños chilenos. Rev Panam Salud Pública 2009, 26:101-111.

91. Berezin E, Hong T, Markowitz J, Seljan MP: Epidemiology and outcomes of hospitalizations due to pneumonia in young children living in Brazil between 2003 and 2007, Presented at: 6th Annual Meeting of the World Society for Pediatric Infectious Diseases. Buenos Aires: WSPID; 2009 [http:// www.abstractserver.com/wspid09/planner/sp.php? go=abstract\&action=abstract_iplanner\&absno=103]

92. Cedrès A, Sobrero H, Giachetto A, Algorta G, Montano A, Pirez MC: 7-valent pneumococcal conjugate vaccine mass vaccination. Bacterial pneumonia admissions in children before and during the year of intervention. Uruguay, Presented at: 6th Annual Meeting of the World Society for Pediatric Infectious Diseases. Buenos Aires: WSPID; 2009 [http://www.abstractserver.com/ wspid09/planner/sp.php?go=abstract\&action=abstract_ iplanner\&absno=793]

93. Giglio N, Cane A, Ferreiros E: Evaluation of cost-effectiveness of three vaccination scenarios with pneumococcal conjugated vaccines, Presented at: 6th Annual Meeting of the World Society for Pediatric Infectious Diseases. Buenos Aires: WSPID; 2009 [http://www.abstractserver.com/wspid09/ planner/sp.php?go=abstract\&action=abstract_iplanner\&absno=314]

94. González Ayala S, Vescina C, Agosti M, Morales J, Marone J, Regueira M, Moriconi L: Pneumococcal meningitis at an Argentinean municipality, Presented at: 7th International Symposium on Pneumococci and Pneumococcal Diseases (ISPPD-7). Tel-Aviv, Israel; 2010 [http://www. abstractserver.com/isppd2010/planner/sp.php? goabstract\&actionabstract_iplanner\&absno=520\&ISPPD2010= 6f9ter81 ucelvs98apjgo40pe1\&ISPPD20106f9ter81 ucelvs98apjgo40pe1]

95. Gutierrez S, Boix Al, Gotelo G, Silva L: Bacterial pneumonia. Hospital admission to the Sindicato Medico Uruguay (CASMU) one year before and after introduction of 7-valent pneumococcal vaccine, Presented at: 6th Annual Meeting of the World Society for Pediatric Infectious Diseases. Buenos Aires: WSPID; 2009 [http://www.abstractserver.com/wspid09/planner/sp.php? go=abstract\&action=abstract_iplanner\&absno=455]

96. Giglio ND, Cane AD, Micone P, Gentile A: Cost-effectiveness of the CRMbased 7-valent pneumococcal conjugated vaccine (PCV7) in Argentina. Vaccine 2010, 28:2302-2310.

97. Grupo de Trabajo de SIREVA II: Informe Regional de SIREVA II: Organización Panamericana de la Salud. Informe Regional de SIREVA II, 2009: datos por país y por grupo de edad sobre las características de los aislamientos de Streptococcus pneumoniae, Haemophilus influenzae y Neisseria meningitidis en procesos invasivos. (Serie Documentos técnicos. Tecnologías esenciales de salud. THS/EV-2009/002). Washington: OPS; 2010.

98. Brandileone MC, Vieira VS, Casagrande ST, Zanella RC, Guerra ML, Bokermann S, De Moraes JC, Baldacci ER, Chamone CB, Oliveira MA, De Matos DG, Arruda TM, Coelho MF, D'Avila SM, Dos Santos AR, Di Fabio JL: Prevalence of serotypes and antimicrobial resistance of Streptococcus pneumoniae strains isolated from Brazilian children with invasive infections. Pneumococcal Study Group in Brazil for the SIREVA Project. Regional System for Vaccines in Latin America. Microb Drug Resist 1997, 3:141-146.

99. Castañeda E, Leal AL, Castillo O, De La Hoz F, Vela MC, Arango M, Trujillo H, Levy A, Gama ME, Calle M, Valencia ML, Parra W, Agudelo N, Mejía Gl, Jaramillo S, Montoya F, Porras H, Sánchez A, Saa D, Di Fabio JL, Homma A: Distribution of capsular types and antimicrobial susceptibility of invasive isolates of Streptococcus pneumoniae in Colombian children. Microb Drug Resist 1997, 3:147-152.

100. Echániz-Aviles G, Velázquez-Meza ME, Carnalla-Barajas MN, Soto-Noguerón A, Solórzano-Santos F, Pérez Miravete A, Gatica-Marquina R, di Fabio JL: Antimicrobial susceptibilities and capsular types of invasive Streptococcus pneumoniae isolated in children in Mexico City. Microb Drug Resist 1997, 3:153-157.

101. Hortal M, Algorta G, Bianchi I, Borthagaray G, Cestau I, Camou T, Castro M, De Los Santos M, Diez R, Dell'Acqua L, Galiana A, Giordano A, Giordano P, Lopez-Ghemi G, Milanese N, Mogdasy C, Palacio R, Pedreira W, Pisano A, Pivel L: Capsular type distribution and susceptibility to antibiotics of Streptococcus pneumoniae clinical strains isolated from Uruguayan children with systemic infections. Microb Drug Resist 1997, 3:159-164.

102. Rossi A, Ruvinsky R, Regueira M, Corso A, Pace J, Gentile A, Di Fabio JL: Distribution of capsular types and penicillin-resistance of strains of Streptococcus pneumoniae causing systemic infections in Argentinean children under 5 years of age. Streptococcus pneumoniae Working Group. Microb Drug Resist 1997, 3:135-140.

103. Kertesz DA, Di Fabio JL, de Cunto Brandileone MC, Castañeda E, EchánizAviles G, Heitmann I, Homma A, Hortal M, Lovgren M, Ruvinsky RO, Talbot JA, Weekes J, Spika JS: Invasive Streptococcus pneumoniae infection in Latin American children: results of the Pan American Health Organization Surveillance Study. Clin Infect Dis 1998, 26:1355-1361.

104. Tomasz A, Corso A, Severina EP, Echániz-Aviles G, Brandileone MC, Camou T, Castañeda E, Figueroa O, Rossi A, Di Fabio JL: Molecular epidemiologic characterization of penicillin-resistant Streptococcus pneumoniae invasive pediatric isolates recovered in six Latin-American countries: an overview. Microb Drug Resist 1998, 4:195-207. 
105. Levine MM, Lagos R, Levine OS, Heitmann I, Enriquez N, Pinto ME, Alvarez AM, Wu E, Mayorga C, Reyes A: Epidemiology of invasive pneumococcal infections in infants and young children in Metropolitan Santiago, Chile, a newly industrializing country. Pediatr Infect Dis J 1998, 17:287-293.

106. Leal AL, Castañeda E: Susceptibility to antimicrobial agents in isolates of invasive Streptococcus pneumoniae in Colombia. Pan Am J Public Health 1999, 5:157-163.

107. Gomez Barreto D, Calderon-Jaimes E, Rodriguez RS, De Los Monteros LEE: Clinical outcome of invasive infections in children caused by highly penicillin-resistant Streptococcus pneumoniae compared with infections caused by penicillin-susceptible strains. Arch Med Res 2000, 31:592-596.

108. Hortal M, Ruvinsky R, Rossi A, Agudelo Cl, Castañeda E, Brandileone C, Camou T, Palacio R, Echániz G, Di Fabio JL: Impacto de Streptococcus pneumoniae en las neumonías del niño latinoamericano. Grupo SIREVAVigía1. Rev Panam Salud Pública 2000, 8:185-195.

109. Hortal M, Lovgren M, de la Hoz F, Agudelo Cl, Brandileone MC, Camou T, Casagrande S, Castañeda E, Corso A, Echaniz G, Hormazabal JC, Pace J Palacio R, Perez-Giffoni G, Ruvinsky R, Di Fabio JL, the PAHO SIREVA-Vigía Study Groups: Antibiotic resistance in Streptococcus pneumoniae in six Latin American countries: biological and therapeutic implications. Microb Drug Resist 2001, 7:391-401.

110. Nascimento-Carvalho CM, Lopes AA, Gomes MD, Magalhães MP, Oliveira JR, Vilas-Boas AL, Ferracuti R, Brandileone MC, Guerra ML, Alves NN, Athayde LA, Caldas RM, Barberino MG, Duarte J, Brandão MA, Rocha H, Benguigui Y, Di Fabio JL: Community acquired pneumonia among pediatric outpatients in Salvador, Northeast Brazil, with emphasis on the role of pneumococcus. Braz J Infect Dis 2001, 5:13-20.

111. Rey LC, Wolf B, Moreira JL, Milatovic D, Verhoef J, Farhat CK: Antimicrobial susceptibility and serotypes of nasopharyngeal Streptococcus pneumoniae in children with pneumonia and in children attending day care centres in Fortaleza, Brazil. Int J Antimicrob Agents 2002, 20:86-92.

112. Ruvinsky R, Gentile A, Regueira M, Corso A: Infecciones invasivas por Streptococcus pneumoniae: estudio epidemiológico e importancia del desarrollo de un sistema de vigilancia. Arch Argent Pediatr 2002, 100:3143.

113. Camou T, Palacio R, Di Fabio JL, Hortal M: Invasive pneumococcal diseases in Uruguayan children: Comparison between serotype distribution and conjugate vaccine formulations. Vaccine 2003, 21:2102-2105.

114. Grupo Multifuncional de Neumonías: Vigilancia epidemiológica centinela de Haemophilus influenzae y Streptococcus pneumoniae en menores de 5 años en el Perú. Rev Peru Med Exp Salud Pública 2003, 20:150-155.

115. Magalhaes AP, Pinto AS: Antimicrobial resistance and serotyping Streptococcus pneumoniae isolated from pediatric patients in Bello Horizonte, MG, Brazil. Braz J Microbiol 2003, 34:210-212.

116. Moreno J, Phandanouvong V, Castañeda E: Vigilancia molecular de aislamientos invasores de Streptococcus pneumoniae resistentes a la penicilina en niños colombianos menores de 5 años. Biomédica 2004, 24:296-301.

117. Ochoa TJ, Rupa R, Guerra H, Hernandez H, Chaparro E, Tamariz J, Wanger A, Mason EO Jr: Penicillin resistance and serotypes/ serogroups of $S$. pneumoniae in nasopharyngeal carrier children younger than 2 years in Lima, Peru. Diagn Microbiol Infect Dis 2005, 52:59-64.

118. Zemlicková H, Crisóstomo Ml, Brandileone MC, Camou T, Castañeda E, Corso A, Echániz-Aviles G, Pásztor M, Tomasz A: Serotypes and clonal types of penicillin-susceptible Streptococcus pneumoniae causing invasive disease in children in five Latin American countries. Microb Drug Resist 2005, 11:195-204.

119. Agudelo Cl, Moreno J, Sanabria OM, Ovalle MV, Di Fabio JL, Castañeda E: Streptococcus pneumoniae: Evolución de los serotipos y los patrones de susceptibilidad antimicrobiana en aislamientos invasores en 11 años de vigilancia en Colombia (1994 -2004). Grupo colombiano de trabajo en S. pneumoniae. Biomédica 2006, 26:234-249.

120. Bricks LF, Berezin E: Impact of pneumococcal conjugate vaccine on the prevention of invasive pneumococcal diseases. J Pediatr (Rio J) 2006 82(3 Suppl):S67-S74

121. Lagos RM, Muñoz AE, Levine MM: Prevalence of pneumococcal bacteremia among children $<36$ months of age presenting with moderate fever to pediatric emergency rooms of the Metropolitan Region (Santiago), Chile. Human Vaccines 2006, 2:129-133.
122. Tique V, Alvis N, Parodi R, Bustos A, Mattar S: Meningitis agudas en Córdoba, Colombia 2002-2004. Rev Salud Pública (Bogota) 2006, 8(Suppl 1):33-46

123. Tregnaghi $M$, Ceballos $A$, Rüttimann $R$, Ussher J, Tregnaghi $P$, Peeters $P$, Hausdorff WP: Active epidemiologic surveillance of pneumonia and invasive pneumococcal disease in ambulatory and hospitalized infants in Cordoba, Argentina. Pediatr Infect Dis J 2006, 25:370-372.

124. Ferrari Castilla AM, Pirez GMC, Martínez AA, Algorta RG, Chamorro VF, Guala BMJ, Zabala Ch C, Giachetto LG, Montano LA: Etiología de la neumonía bacteriana adquirida en la comunidad en niños hospitalizados. Uruguay 1998-2004. Rev Chilena Infectol 2007, 24:40-47.

125. Lovgren M, Talbot JA, Brandileone MC, Casagrande ST, Agudelo Cl, Castañeda E, Regueira M, Corso A, Heitmann I, Maldonado A, Echániz-Aviles G, Soto-Noguerón A, Hortal M, Camou T, Gabastou JM, Di Fabio JL, SIREVA Study Group: Evolution of an international external quality assurance model to support investigation of Streptococcus pneumoniae, developed for the SIREVA Project in Latin America, from 1993 to 2005. J Clin Microbiol 2007, 45:3184-3190

126. Vieira A, Gomes C, Rolo M, Eudes J, Bello EJM, Fiqueiredo R: Streptococcus pneumoniae: estudo das cepas isoladas de liquor. J Pediatr (Rio J) 2007, 83:71-78.

127. Abarca VK, Vergara FR, Tassara PE, Ibanez WI, Garcia BC, Potin SM: Invasive pneumococcal disease and consolidated pneumonia in infants: one year of surveillance in three Chilean health care centers. Rev Chilena Infectol 2008, 25:97-103. SIREVA.

128. Gabastou JM, Agudelo Cl, Brandileone MC, Castañeda E, de Lemos AP, Di Fabio JL: Caracterización de aislamientos invasivos de $S$. pneumoniae, $H$. influenzae y N. meningitidis en América Latina y el Caribe: SIREVA II, 2000-2005. Rev Panam Salud Pública 2008, 24:1-15.

129. Hortal M, Sehabiague G, Camou T, Iraola I, Estevan M, Pujadas M: Pneumococcal pneumonia in hospitalized Uruguayan children and potential prevention with different vaccine formulations. J Pediatr 2008, 152:850-853.

130. Mayoral C, Baroni MR, Giani R, Virgolini S, Zurbriggen L, Regueira M: Distribución de serotipos de Streptococcus pneumoniae aislados de infecciones invasoras en el Hospital de Niños de Santa Fe. Rev Argent Microbiol 2008, 40:13-16.

131. Pírez García MC, Giachetto Larraz G, Romero Rostagno C, Zabala Chain C, Algorta Rusiñol G, Montano Lotito A, Ferrari Castilla AM: Neumonía neumocócica invasiva en niños de 0 a 24 meses: ¿influye la resistencia bacteriana en la evolución? An Pediatr (Barc) 2008, 69:205-209.

132. Agudelo $\mathrm{Cl}$, Castañeda $E$, Corso A, Regueira M, Brandileone MC, Brandão AP, Maldonado A, Hormazabal JC, Tamargo I, Echániz-Aviles G, Soto A, Viveros MG, Hernández I, Chamorro G, Weiler N, Sánchez J, Feris JM, Camou T, García G, Spadola E, Payares D, Gabastou JM, Di Fabio JL, Grupo Sireva II: Resistencia a antibióticos no betalactámicos de aislamientos invasores de Streptococcus pneumoniae en niños latinoamericanos. SIREVA II, 2000-2005. Rev Panam Salud Pública 2009, 25:305-313.

133. Mantese OC: Prevalence of serotypes and antimicrobial resistance of invasive strains of pneumococcus in children: analysis of 9 years. $J$ Pediatr (Rio J) 2009, 85:495-502.

134. Lagos R, Muñoz A, Valenzuela MT, Heitmann I, Levine MM: Populationbased surveillance for hospitalized and ambulatory pediatric invasive pneumococcal disease in Santiago, Chile. Pediatr Infect Dis J 2002, 21:1115-1123

135. Dickinson FO, Pérez AE: Bacterial meningitis in children and adolescents: an observational study based on the national surveillance system. BMC Infect Dis 2005, 5:103.

doi:10.1186/1471-2334-12-124

Cite this article as: Castañeda et al:: Streptococcus pneumoniae serotype 19A in Latin America and the Caribbean: a systematic review and metaanalysis, 1990-2010. BMC Infectious Diseases 2012 12:124. 